\title{
Por dentro do caleidoscópio: história e memória político-cultural em Manhã cinzenta, de Olney São Paulo
}

\author{
Antonia Cristina de Alencar Pires* \\ Gustavo Tanus ${ }^{\dagger}$ \\ Filipe Schettini ${ }^{\ddagger}$
}

Luz, câmera, "claquete”

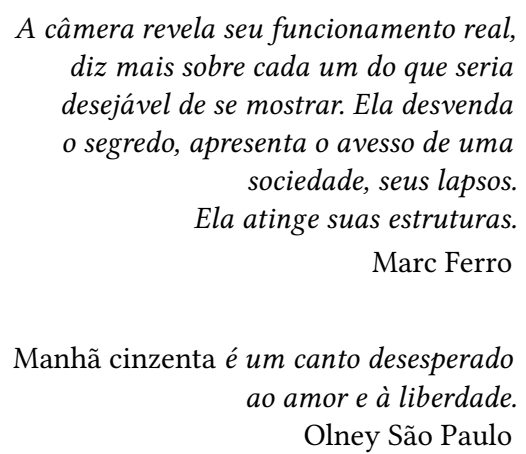

Prosseguir em busca da superação de traumas causados pela experiência violenta e autoritária da ditadura civil-militar de 1964 pressupõe que tenhamos uma responsabilidade ética de, neste momento, analisar os períodos de suspensão dos direitos dos cidadãos, da democracia, não tratando-os como objetos de fetiche arqueológico, mas buscando analisá-los como eventos históricos, que foram construídos/permitidos por ideologias e atores sociais conservadores que não foram extintos com a redemocratização. Estes e suas ideias, embora modificadas no sen-

\footnotetext{
Doutora em literatura comparada e técnica em gestão, proteção e restauro do Instituto Estadual do Patrimônio Histórico e Artístico de Minas Gerais (IEPHA/MG), Belo Horizonte, MG, Brasil. E-mail: crisp563@gmail.com

$\dagger$ Doutorando em estudos da linguagem na Universidade Federal do Rio Grande do Norte (UFRN), Natal, RN, Brasil. E-mail: gustavotcs@gmail.com

¥ Graduando em Cinema e Audiovisual no Centro Universitário Una, Belo Horizonte, MG, Brasil. E-mail: filipe.schettini@outlook.com
} 
tido de agregar outros argumentos, lidos de forma deturpada, são base do espectro conservador que ronda o momento presente.

Assim, nosso objetivo é realizar uma leitura do média-metragem Manhã cinzenta, do cineasta Olney São Paulo, lançado em 1969, que é um dos mais significativos filmes da resistência à ditadura civil-militar de 1964, como também é uma espécie de metáfora da vida do próprio cineasta, afigurando-se como uma ferida em seu corpo estilhaçado pela tortura, pela ousadia de produzi-lo, em plena vigência do Ato Institucional $\mathrm{n}^{\circ} 5$ - este que permitira a censura prévia às produções culturais e à mídia, o toque de recolher, o ataque desigual aos não cooperativos com o golpe, e a perda das garantias individuais, com a suspensão do habeas corpus, o que possibilitava a prisão injusta, arbitrária e violenta e também a coação dos cidadãos que os golpistas julgassem serem contrários ao regime - reflexões sobre a história e a memória político-cultural de uma época de autoritarismo e repressão, importantes para a análise do tempo atual, de ameaça à democracia no Brasil e no mundo.

O filme em questão, em síntese, é uma grande alegoria dos regimes ditatoriais latino-americanos daquele momento, da manhã acinzentada da pandemia ditatorial que se iniciou nos anos de 1960 nos países da América Latina, e retrata o massacre perpetrado pelos militares contra uma resistência civil, mormente composta por um corpo de jovens e de operários. Para nossa leitura e análise, partimos dos pressupostos de Marc Ferro (1971; 1992) e de Robert Rosenstone (2010) de que os filmes e os arquivos fílmicos podem suprir a ausência dos documentos oficiais tradicionais, dos quais a história lança mão para construir seu discurso, contribuindo, assim, para a construção historiográfica, sendo também fontes para a compreensão de contextos e de acontecimentos históricos. Eles são, portanto, suplementares, no sentido dado por Derrida (1995), não sendo apenas algo pleno que acresceria, complementarmente, outro pleno, mas aquilo que viria a suprir uma falta (as lacunas dos arquivos oficiais?), e, na medida em que substitui e supre essa falta, seria capaz de provocar um descentramento na narrativa da história.

Com efeito, cumpre-nos assinalar que não por acaso elegemos como iluminadores de nosso percurso aqui os postulados dos teóricos mencionados, os quais corroboram a ideia de que as narrativas fílmicas são capazes de produzir/reestruturar o conhecimento acerca da história e da memória cultural de um dado momento.

\section{Olney São Paulo, o cineasta maldito do sertão: notas biofilmográfi- cas}

A presença do Manhã cinzenta na história do cinema brasileiro é extraordinária e única, assim como a presença de seu autor. É possível dizer que tanto um quanto o outro foram inexoravelmente marcados pelo trágico em seus percursos. Nascido em Riachão do Jacuípe e criado em Feira de Santana, municípios do sertão baiano, desde menino Olney se interessou pela literatura e outras artes, sobretudo pelo 
cinema, cujo fascínio se deu, inicialmente, pelos Westerns americanos e, depois, pela melancolia e a introspecção das imagens em preto e branco do Neorrealismo italiano.

O movimento italiano em questão, diretamente influenciado pelo Realismo poético francês, tinha como objetivo inicial se opor à estética fascista, até então adotada na Itália, e tratar de forma realista, imersiva e intimista a situação em que o país e suas classes populares se encontravam ao fim da Segunda Guerra Mundial. O movimento que impulsionou o cinema italiano, cujo substrato são temáticas sociais e políticas, impactou as "Novas Ondas" e outros movimentos cinematográficos que se seguiram, como a Nouvelle Vague francesa, a New Wave britânica ou o Cinema Novo brasileiro.

A filosofia também ocupava a atenção do futuro cineasta, principalmente o Existencialismo, que se tornara popular após a Segunda Guerra Mundial, ainda que tenha surgido no século XIX, com os filósofos Kierkegaard, Schopenhauer e Nietzsche. Olney identificava-se com os postulados dessa corrente filosófica, que, entre outras ideias, considerava que o indivíduo está condenado a viver num mundo absurdo e que a tragédia pode se abater sobre aqueles que ousam lutar contra os absurdos. Dentre os existencialistas do século XX, Albert Camus era o de sua predileção, talvez por este filósofo e escritor argelino ser também um militante de causas político-sociais. Tanto o Neorrealismo quanto o Existencialismo, estéticas oriundas das ruínas do pós-guerra e dos regimes totalitários, as quais buscam apontar o valor da liberdade para a vida humana, deixariam marcas profundas no pensamento e na obra de Olney.

O rapaz do sertão baiano fez, aos 19 anos, sua profissão de fé em carta dirigida ao cineasta Alex Viany, um dos precursores do movimento Cinema Novo, que filmava em Feira de Santana um dos episódios do longa-metragem Rosa dos ventos e em cuja equipe ele participara como figurante: "Eu sou um jovem que tem inclinação invulgar para o cinema. Porém, como neste mundo aquilo que mais desejamos nos foge sempre da mão, eu luto com incríveis dificuldades para alcançar meu objetivo" (José, 1999, p. 29).

O fragmento aqui transcrito, além de esboçar sua profissão de fé, tornaria-se também uma espécie de autoprofecia sobre sua própria vida. Olney sempre teve grandes dificuldades para realizar seus projetos, deixando muitos inacabados. ${ }^{1}$

Em depoimento sobre Olney São Paulo publicado no site da Empresa de Processamento de Dados do Município de Porto Alegre (Procempa), o cineasta Orlando Senna afirma: "todos os seus filmes foram realizados do jeito como realizou o primeiro, Crime na Rua: com produção escassa, apoio da família e de amigos (os tinha em quantidade), superação de qualquer dificuldade. Alguns mais, outros menos, todos foram uma batalha pessoal, um corpo-a-corpo com arma branca, um enfrentamento de vida ou morte. E em todos a realidade brasileira nua e crua segundo o seu ponto de vista onde a sabedoria arcaica do sertão e a cultura sofisticada do ocidente resultam em indignação e humanismo" (SENNA, 2011, p. 11). 
A participação na equipe de Viany inaugurava, assim, a filiação de Olney ao movimento Cinema Novo, que surgira no espírito das "novas ondas" já mencionadas e, principalmente, após o I Congresso Nacional do Cinema Brasileiro, ocorrido em 1952, no qual se discutiu sobre a necessidade de uma linguagem cinematográfica própria do país, após o fracasso da produtora Vera Cruz. Imbuídos dessa necessidade, cineastas alinharam seu pensamento em torno de uma estética cinematográfica empenhada em representar, de forma realista e engajada, os problemas brasileiros.

O jovem cineasta passa a desenvolver seus projetos dentro da estética cinemanovista e, paralelamente a eles, Olney trabalhava como bancário, jornalista e produtor teatral, agitando a cena cultural de Feira de Santana. Sua inserção definitiva no movimento Cinema Novo se daria ao integrar a equipe de realização do filme Mandacaru vermelho, dirigido por Nelson Pereira dos Santos, rodado em cidades baianas em 1961, no qual foi continuista da produção e assistente de direção e produção, além de também compor o elenco.

Em 1963, aproximou-se de Glauber Rocha e seu grupo em Salvador. Três anos depois chegaria ao Rio de Janeiro para residir, já com problemas com a censura federal, em decorrência do longa-metragem em preto e branco $O$ grito da terra (baseado em romance homônimo do escritor baiano Ciro de Carvalho Leite), realizado em 1964. Lembramos aqui que a censura às produções audiovisuais naquele momento se fazia de forma drástica, como demonstra Leonor Sousa Pinto (2005), por serem os filmes e seus realizadores considerados propagandistas de ideias contrárias ao regime autoritário que se instalara no país por meio de um golpe militar apoiado por setores da sociedade civil (empresários, latifundiários e segmentos da classe média urbana). Esse filme é marcadamente cinemanovista, não apenas do ponto de vista da temática mas também das condições de sua produção, realizada com o mínimo de recursos técnicos e financeiros. ${ }^{2}$

No ano de 1968, a ditadura civil-militar tornara-se ainda mais repressiva, com a edição dos Atos Institucionais, decretos que legislavam acima da Constituição e com a vigilância intensa sobre tudo e todos. Em razão disso, intensificam-se os protestos de rua no Rio de Janeiro. Desde março daquele ano, quando foi assassinado pela polícia o estudante secundarista Edson Luís de Lima Souto no Restaurante Calabouço, até 13 de dezembro, ${ }^{3}$ dia em que foi decretado o Ato Institucional $\mathrm{n}^{\circ} 5$ (AI-5), as passeatas organizadas pelo movimento estudantil tomavam as ruas do centro da cidade, gerando confrontos com as forças de repressão, cujo saldo eram pessoas feridas, mortas ou presas. É nesse contexto violento e obscuro que Olney resolve filmar um longa-metragem composto de três episódios. Um deles tem como base para o roteiro o conto de sua autoria, "Manhã cinzenta", escrito em

\footnotetext{
2 Entre 1961 e 1976, Olney realizou grande número de curtas, médias e documentários, além do longa-metragem $O$ Forte, baseado no romance homônimo de Adonias Filho.

3 Ver acervo on-line Memórias da ditadura, do Instituto Vladimir Herzog. Disponível em: <http: //memoriasdaditadura.org.br>. Acesso em: 26 jun. 2017.
} 
1966 e publicado posteriormente na coletânea $A$ antevéspera e o canto do sol: contos e novelas (1969), que reúne outros textos do cineasta. Ele tencionava representar aquele momento da história brasileira não apenas por meio de uma ficção realista, mas agregando a ela registros de acontecimentos reais, no caso: os protestos de rua e as passeatas, conjugando assim, no mesmo trabalho, ficção e documentário.

Filmado entre 1968 e 1969, Manhã cinzenta se tornaria não apenas um dos mais significativos filmes da resistência à ditadura civil-militar como se transformaria, conforme já afirmamos, numa espécie de metáfora do próprio Olney, uma ferida em seu corpo, uma vez que, por causa dele, o cineasta foi preso e torturado, o que lhe deixou sequelas físicas e psíquicas, vindo a morrer anos depois em consequência delas, tal como outros perseguidos pelo regime autoritário, como Frei Tito, Maria Auxiliadora Lara Barcelos (Dodora) e Vera Sílvia Magalhães.

Em Revolução do Cinema Novo (1981), Glauber Rocha relaciona o filme e o cineasta como um amálgama indissociável, como se película e pele/corpo fossem uma coisa só:

Olney é a Metáfora de uma Alegorya. Retirante dos sertões para o litoral - o cineasta foi perseguido, preso e torturado [...] Manhã cinzenta é o grande filmexplosão [...] Montagem caleidoscópica desintegra signos da luta contra o Syztema - panfleto bárbaro e sofisticado, revolucionário a ponto de provocar prisão, tortura e iniciativa mortal no corpo do Artysta. O Cinema Nordestino, Cinema Popular metaforizado em Olney e Miguel Torres vítimas dos invasores - Heroys do Brazyl! (RochA, 1981, p. 366).

Ângela José, a biógrafa do cineasta, reitera que:

Pela primeira vez no país, um cineasta era processado por ter realizado um filme. Em geral as obras eram mutiladas ou totalmente censuradas, e os artistas eram presos por suas ideias ou participações em grupos políticos (José, 1999, p. 112).

Como todas as produções culturais realizadas naquele momento, o filme foi submetido ao crivo do Serviço de Censura de Diversões Públicas e não foi liberado para exibição, sob a alegação de que era altamente subversivo, "seja do ponto de vista das cenas apresentadas, seja dos diálogos que encerra, formando, no conjunto uma imagem nociva ao regime", incitando o povo contra as autoridades constituídas, especialmente contra os militares. O argumento do Serviço de Censura levou Olney a ser incurso na Lei de Segurança Nacional e os negativos e as cópias do filme foram confiscados e destruídos, conforme descreve Maria Davi Santos (2011; 2013). Uma delas, entretanto, que havia sido enviada à Federação Carioca de Cineclubismo, foi exibida dentro de um avião que fora sequestrado e desviado para Cuba pelo grupo guerrilheiro MR-8, em outubro de 1969. O episódio complicou ainda mais a situação do cineasta e resultou na já mencionada prisão 
de Olney, que experimentaria, tal como os personagens de seu filme, a tortura e um julgamento kafkiano. Os regimes ditatoriais não autorizam a consciência crítica dos sujeitos. Ademais, é inerente a tais regimes adequar a verdade e a realidade a conceitos criados por eles próprios.

Cumpre-nos informar que algumas cópias já haviam sido enviadas para outros países para participação em festivais de cinema. ${ }^{4} \mathrm{~A}$ única que restou no Brasil é a que permaneceu escondida na cinemateca do Museu de Arte Moderna do Rio de Janeiro e localizada 25 anos depois. Nos últimos anos muitos estudos têm sido elaborados sobre Olney e seu corpus cinematográfico. Apesar de tais estudos, do Projeto de Lei que instituiu como dia do Documentário o dia 7 de agosto (data do nascimento do cineasta) e de dois documentários metalinguísticos - Ser tão cinzento (2011) e sua continuação, Sinais de cinza: a peleja de Olney contra o dragão da maldade (2017), de Henrique Dantas - a figura de Olney é quase esquecida na historiografia do cinema brasileiro, reverberando a "litania dos vencidos" pela ditadura civil-militar de 1964. Nas mencionadas pesquisas, sublinhamos, sempre há destaque para Manhã cinzenta, em razão de sua singularidade e das circunstâncias que o envolvem. Tal como o ano no qual foi realizado, ele ainda não acabou. ${ }^{5}$

\section{O contradiscurso de Manhã cinzenta}

Levando em conta o contexto de sua realização, Manhã cinzenta se apresenta como um contradiscurso ao discurso da ditadura civil-militar, apontando a precariedade de seus nexos e a gratuidade de sua violência. Para observá-lo enquanto tal, apoiamo-nos, como afirmado anteriormente, nas proposições do historiador francês Marc Ferro, pioneiro no estudo dos filmes como fontes históricas. No artigo "O filme, uma contra-análise da sociedade", escrito em 1971, o referido historiador afirma que as imagens produzidas pelo cinema, quer sejam elas ficcionais ou não, inscrevem-se como uma contra-análise da sociedade que (re)apresentam, constituindo-se em matéria de uma Outra História, ou nas palavras do próprio Ferro:

O que é evidente no caso dos “documentos", os filmes de notícias, não é menos verdadeiro no caso da ficção. A porção do inesperado, do involuntário, pode ser muito grande aí. [...] Esses lapsos de um criador, de uma ideologia, de uma sociedade constituem reveladores privilegiados. Eles

4 Foi exibido na Itália, no Festival de Pesaro; no Festival Internacional de Cinema de Viña del Mar; na Quinzena de Realizadores do Festival de Cannes em 1970. Participou também da XIX Semana Internacional de Mannheim, conquistando o prêmio de melhor média-metragem. Foi premiado no Festival de Oberhausen, na Alemanha, em 1972.

5 Destacamos aqui os trabalhos realizados pelos pesquisadores do Núcleo de Estudos em Literatura e Cinema (NELCI) da Universidade Estadual de Feira de Santana (UEFS), além de vários artigos avulsos publicados em sites e blogs. 
podem se produzir em todos os níveis do filme, como também em sua relação com a sociedade. Analisar tais lapsos, bem como suas concordâncias ou discordâncias com a ideologia, ajudam a descobrir o que está latente por trás do aparente, o não-visível através do visível. Aí existe a matéria para uma outra história, que certamente não pretende constituir um belo conjunto ordenado e racional, como a História; mas contribuiria, antes disso, para refiná-la ou destruí-la (FERro, 1992, p. 88).

Para que o filme ou as imagens fílmicas venham a se tornar a matéria dessa Outra História, Ferro propõe a seguinte metodologia de análise, a qual buscamos seguir neste artigo:

[...] analisar no filme tanto a narrativa quanto o cenário, a escritura, as relações do filme com aquilo que não é filme: o autor, a produção, o público, a crítica, o regime de governo. Só assim se pode chegar à compreensão não apenas da obra, mas também da realidade que ela representa (FERRO, 1992, p. 87).

Nessa mesma ordem de ideias, consideramos também que o média-metragem Manhã cinzenta pode ser pensado como um filme do tipo "drama experimental ou inovador", tal como formulado por Robert Rosenstone em A história nos filmes, os filmes na história (2010). Conforme definição do historiador estadunidense, que se notabilizou por seus estudos sobre a relação entre cinema e história, o "drama experimental" é um tipo de filme com uma abordagem politicamente crítica da realidade representada. Rosenstone, ao criar tal categoria de filmes dentro do universo dos chamados filmes históricos, buscou apontar como o "drama experimental ou inovador" se relaciona com o discurso histórico do qual se origina e ao qual se refere. Para entender a rede de significações que emerge de tal relação, Rosenstone utilizou o método do cotejamento entre o filme tomado como objeto de análise e o contexto social e político no qual ele foi realizado, demonstrando, assim, como o "drama inovador ou experimental" revela-se como fonte da história e da memória desse mesmo contexto (Rosenstone, 2010, p. 82 apud Nicolazzi, 2011, p. 194). Além de analisarmos Manhã cinzenta como um contradiscurso ao discurso autoritário do regime militar e o considerarmos um drama experimental, não perdemos de vista, em nossas observações do filme, as considerações de Glauber Rocha sobre o média-metragem de Olney.

Essas considerações estendem-se em duas direções. A primeira diz respeito ao caráter político do filme ("panfleto bárbaro e sofisticado, revolucionário"). Nesse sentido, consonantes com Glauber e assentados nas proposições de Ferro, reiteramos que Manhã cinzenta apresenta-se como um contradiscurso, um contraponto ao discurso autoritário e ordenador do regime militar brasileiro (e por extensão a toda forma de opressão), ao indiciar a supressão das liberdades individuais, o aniquilamento dos sujeitos nos regimes de exceção, uma vez que o filme mescla referências ao nazismo com imagens reais da violência perpetrada pelo Estado ditato- 
rial brasileiro contra os que julgava seus opositores, fossem eles militantes políticos ou não.

A segunda direção das considerações glauberianas refere-se à própria composição do filme ("montagem caleidoscópica desintegradora de signos"). A palavra caleidoscópio, de origem grega, significa "olhar para belas imagens" e, por si só, já explica o próprio objeto, que é um aparelho óptico formado por um tubo de papelão ou de metal, dentro do qual existem pequenos fragmentos de vidro colorido, que, através do reflexo da luz exterior em pequenos espelhos inclinados, apresentam, cada vez que se movimenta o tubo, combinações e efeitos visuais variados. Ocorre-nos pensar que Glauber caracterizou Manhã cinzenta como um caleidoscópio, intencionando salientar não apenas a questão técnica da montagem, como também seu caráter fragmentário e polissêmico, visto que a cada novo olhar, o espectador percebe elementos novos em suas imagens. Todavia, o que se vê nesse caleidoscópio são imagens da dor, da dilaceração, do sombrio, soando ironicamente trágica a metáfora glauberiana. Convém assinalar que a ironia trágica ou dramática, como se verá adiante, emoldura várias cenas do filme em questão.

Isso posto, a leitura do média-metragem Manhã cinzenta que ora segue está pautada na observação de todos os aspectos aqui levantados, bem como dos elementos de seu contexto originário, com o intuito de compreendê-lo como memória política e cultural dos anos de repressão no Brasil do final da década de 1960.

O enredo do filme se desenrola em torno de um casal de estudantes [Alda e Sílvio] que segue para uma passeata, onde o rapaz, um militante, lidera um comício. Eles são presos durante a manifestação, torturados na prisão e sofrem um inquérito absurdo dirigido por um robô e um cérebro eletrônico. No inquérito, a atriz usa uma toga romana e o ator veste-se como Tiradentes. O diálogo é uma adaptação dos Autos da Devassa (José, 1999, p. 98).

O filme inicia com a imagem da rua, com a sinalização de via - uma seta apontando em direção ao espectador. Ao som da canção Gloria, que integra a Misa Criolla, ${ }^{6}$ ouve-se: "Gloria a Dios / en las alturas / y en la tierra paz a los hombres, / [...] paz a los hombres / que ama el Señor" (RAmírez, 1964). A canção em questão inscreve-se duplamente irônica na cena de abertura, sublinhando o viés trágicodramático das situações narradas dali em diante, pois a paz entre as pessoas é justamente aquilo que não foi celebrado, naqueles momentos de repressão. Por outro lado, nos recordamos da "paz" preconizada pelas manifestações de março de 1964,

\footnotetext{
6 Composta pelo músico argentino Ariel Ramírez, no chamado boom do folclore, que foi um movimento ocorrido na Argentina, de aproximação da cultura popular. Como disse Díaz, "se tematiza en las canciones toda una línea de recuperación de lo 'latinoamericano'. Esto no significa un desconocimiento ni un rechazo de las particularidades regionales” (DíAz, 2004). A obra musical em questão mescla elementos da música erudita a elementos tradição andina, em leitura da tradição religiosa cristã.
} 
nas "Marchas da Família com Deus pela Liberdade", uma série de eventos públicos que representavam uma classe média - expressão maior do conservadorismo - temerosa de uma "ameaça comunista", propagandeada pelos grandes sistemas de informação.

Cabe lembrar que a ironia é uma figura de linguagem, que consiste em apontar o contrário do que está sendo dito ou mostrado, visando denunciar uma determinada situação e causar uma reação no receptor, seja ele leitor, ouvinte ou espectador. Em razão de sua natureza opositiva, a ironia desestabiliza as verdades tomadas como absolutas, desvelando o avesso de certos discursos, pondo a nu suas incongruências. Como nos explica Linda Hutcheon, "uma definição influente e muito citada sugere que a ironia opera onde o signo aponta para algo que difere de seu sentido literal e tem por função tematizar essa diferença” (Hutcheon, 2000, p. 98).

Entre as categorias nas quais se divide a ironia, encontra-se a ironia trágica ou dramática, a qual acabamos de nos referir. Este tipo de ironia está associado às situações que possuem um desfecho trágico e cujos elementos presentes na cena indiciam para o leitor/espectador tal desfecho (ARAGÃo, 2011). Vale lembrar que os já mencionados filósofos existencialistas do século XIX, sobretudo Kierkegaard e Schopenhauer, lançaram mão deste tipo de ironia em seus escritos. Ao nosso ver, a ironia presente em Manhã cinzenta é um elemento desintegrador de signos a que se referiu Glauber ao escrever sobre o média-metragem.

O filme prossegue. Tomadas distantes de um edifício oferecem uma sensação de aparente normalidade, enquanto outras mais perto denunciam o controle. Policiais barram a entrada. Em uma sala de aula, jovens, protagonistas do filme, escutam música, parecem apreensivos, uma jovem dança ao som de uma canção rock and roll, símbolo da rebeldia e liberdade naqueles tempos. A câmera realiza um travelling da janela da sala e permite que o espectador veja a vista da enseada da praia de Botafogo, no Rio de Janeiro, e nesse movimento focaliza a jovem que dança. Ao mostrar a enseada pela janela, a saturação de luz parece sugerir a ocorrência de algo, enquanto os jovens estão ali, dentro da sala de aula.

A cena muda para passeatas (reais) dos estudantes, da resistência ao golpe, há confronto, ao som da marcha The Washington Post, ${ }^{7}$ composta por John Philip Sousa. Novamente a música opera como elemento irônico, lembrando ao espectador o apoio dos Estados Unidos ao golpe brasileiro. Uma voz locutora anuncia pelo rádio a manifestação de professores, estudantes e trabalhadores contra o regime. Uma outra voz, em discurso claramente conservador, em tom de propaganda do golpe anuncia: "repetidas vezes, por muitos e muitos anos, nem nos lembramos mais das ocasiões funestas os infames apregoavam aos ventos, dizendo que nós, as aves de rapina, sobrevoavam-lhes as carcaças para sugar-lhes o sangue e suas

\footnotetext{
7 Os proprietários do jornal The Washington Post pediram a Sousa para compor uma peça para promover um concurso de ensaios que estavam patrocinando. No dia da apresentação, foi executada no momento do anúncio dos vencedores do concurso, e conquistou o público presente. Logo, o jornal ficaria conhecido, por conta dela (BIERLEY, 1973, p. 47-48).
} 
últimas forças, era mentira". Nesse momento, entra o contradiscurso de um jovem que denuncia: "para assumir as ações, eles apareceram circundando as ruas por muitos e muitos anos, e aí estão, voltados contra o povo". Começa a tocar a marcha militar Semper Fidelis, ${ }^{8}$ do mesmo compositor da primeira, na cena em que um dos protagonistas lê o parágrafo final de $A$ peste, de Albert Camus:

[...] o bacilo da peste não morre nem desaparece nunca, pode ficar dezenas de anos adormecido nos móveis e nas roupas, espera pacientemente nos quartos, nas casas, nos lençóis e nas papeladas. E sabia, também, que viria talvez o dia em que, para desgraça e ensinamento dos homens, a peste acordaria seus ratos e os mandaria morrer numa cidade feliz.

A marcha associada ao parágrafo final do livro de Camus - que é uma alegoria para o nazismo e, por extensão, para todo regime autoritário - coloca-nos por meio de fina ironia trágico-dramática a questão do militarismo e seus aplaudentes correligionários, como o "sempre fiel" soldado inquiridor, e as novas adesões da classe média - aos golpistas, como os ratos vetores do bacilo da peste que é o estado de exceção, a intolerância e a violência dos homens. Sílvio avista Alda que chega com o jornal nas mãos. Eles se cumprimentam e ela diz: "É muito difícil, não se resiste mais." A frase musical inicial da música É proibido proibir, de Caetano Veloso ${ }^{9}$ começa a tocar e eles caminham abraçados, entram no ônibus. Sílvio diz que o povo está sendo metralhado pelos caminhos, por aderir às passeatas contra o golpe. E Alda diz: "era necessário fazer alguma coisa, formar um governo de gente que soubesse sorrir, uma nação de povo, um país em que as crianças respirassem alegres e saíssem às ruas entoando um canto de amor" (SÃo PAULO, 1969, 7:22-7:56).

Volta-se, agora, à rua focalizada no início do filme, porém, nesse momento, tomada por fumaça, pela violência da repressão policial. Novamente são imagens reais de uma passeata e da repressão. Retorna-se para a sala de aula, onde os estudantes estavam apreensivos. Agora escutam uma notícia dada pelo rádio: "Verdadeiro massacre foi realizado na tarde de ontem, quando da invasão da associação de empregados do comércio, com espancamento de operários, mestre de obras e de alguns estudantes que prestavam solidariedade aos grevistas" (SÃo PAULO, 1969, 7:56-8:07). A cena retornará, numa circularidade, à sala de aula, onde os jovens, encantoados, conversam sobre a democracia e justiça social, demonstram preocupação. Em uma cena seguinte, Sílvio desce a escadaria, onde subira com Alda, sob uma frase musical do "charango"10 tocado na Misa Criolla. Ele está visivelmente esgotado. Os soldados empurram-no enquanto ele desce. Passa pela câmera, que

8 Essa marcha, composta em 1888, teve o seu nome retirado do lema da Marinha estadunidense. Logo seria adotada como um hino dessa instituição militar (BIERLEY, 1973, p. 47).

9 A canção de Caetano Veloso retoma o lema "é proibido proibir" do movimento estudantil parisiense de maio de 1968.

10 Um pequeno instrumento de cordas andino, tradicionalmente feito a partir da carapaça de Tatu (OXFORD, 2017). 
focaliza o estandarte da Ordem da Concupiscência, que é uma seta que ultrapassa a linha. Esta seta seria uma referência ao sinal da rua focalizado no início do filme?

Há uma passagem emblemática, que é a cena do julgamento de Alda. É um julgamento parcial, numa espécie de tribunal militar, em que um dos soldados na função de acusador diz: "revendo todas as folhas do relatório, comprovamos, dentre os dados apresentados, estar conforme o original, no entanto, existe um pormenor, Excelência! a menina não tem sangue judeu!" E o robô, uma espécie de cérebro eletrônico que compõe a corte de acusação, inquire pergunta, com um tom de deboche: "Sangue judeu?! O que é sangue judeu?". E o julgamento continua:

Juiz: Quem exigiria tão hedionda particularidade? Não! Não era preciso. Bastava somente uma coisa e isso já existia em todos... Isso é um julgamento de cores, inquirimento do verde, o processo do amarelo, a apelação do lilás, a prorrogação do azul, sobretudo, acima de tudo, a condenação perpétua e irrecorrível do vermelho, o matiz da guerra...

Alda: Só existe uma solução.

Acusador: Conseguimos essa solução.

Alda: Não excelência, pensamos uma mudança de coisas, uma transformação de pensamento...

Juiz: O povo não sabe pensar, o povo jamais soube pensar, nós é que conduziremos o povo...

Alda: Para a morte...

(SÃo PAUlO, 1969, 13:45-14:18).

A inquirição da máquina - lido como uma alegoria da ditadura (SANTos, 2013, p. 121) ou como o discurso da Guerra Fria (MACHADO, 2016, p. 7) -, juntamente com a qualificação que ela faz, mais à frente, de Alda, chamando-a de "pervertida, Salomé", numa alusão à dança da moça, mostrada na cena inicial do filme (15:59), e ainda, sobre o discurso de Sílvio, que teria sido guardado em sua memória eletrônica - "safados, foram todos recrutados num cabaré" (16:32) -, demonstram que tal robô é capaz de emitir juízo, sua opinião pessoal. Isso aponta para outro lado, ela pode ser mais que alegoria do estado autoritário, mas também da parcela da população despolitizada, representada pela classe média, que silenciara contra o golpe, fechara os olhos para o massacre e a tortura de jovens, tapando os ouvidos para o que se passava no país naqueles momentos e, mais, daqueles que, em nome da "Ordem da Concupiscência", assumiram a ideologia maniqueísta da Guerra Fria pelo irrefletido medo de que o Brasil virasse uma nova Cuba, sendo contra os que classificavam de subversivos.

Ainda no julgamento é condenada a campanha de alfabetização do governo João Goulart, calcada na metodologia criada pelo educador Paulo Freire, vista como "agitação de massas através de códigos alfabéticos, uma nova forma de ensinar aos homens, às mulheres e às crianças". Um soldado lembra do código da escrita como: "sinais chineses" (SÃo PAULO, 1969, 14:33-14:52), num claro desconhecimento do 
que seja a escrita, a leitura e sua importância para o livre pensamento, que marca as democracias.

Em Manhã cinzenta, o robô, que no imaginário (da época do filme) era a representação de inteligência superior, refletida num pensamento objetivo, avançado, indubitável, e trazia uma ideia de futuro, faz a seguinte relação imperativa dentro de uma ideologia do golpe: "A, água; A, R, ar; M, A, arma” (SÃo PAUlO, 1969, 14:52-15:0o), isso que é justamente o oposto do que preconiza o pensamento freiriano sobre a alfabetização. ${ }^{11}$ Após a sequência lógica do robô, Sílvio, que aparece deitado, agonizante e delirante pronuncia: "A-, mor", palavra que demonstra a humanidade do sujeito, em oposição à lógica da máquina, de acumulação de dados e depósito de informações, o que pode ser relacionado à pedagogia freiriana. Nesse momento toca a canção É proibido proibir, de Caetano Veloso, enquanto passam várias cenas de Sílvio e Alda: "Me dê um beijo, meu amor / Eles estão nos esperando / Os automóveis ardem em chamas" (SÃo PAULO, 1969, 14:33-14:52).

A cena muda para o tribunal. A máquina é convocada a reproduzir o discurso de Sílvio e, enquanto o discurso acontece, entram uma profusão de cenas caleidoscópicas, dele e dos jovens em passeatas. Até que entra uma voz avisando a censura de uma parte do discurso, que é interrompido na voz, porém continua, para nós espectadores, nas imagens da tortura sexual de uma moça que se encontra nua, e de Alda sendo encantoada por soldados. A voz censora diz: "passemos adiante, muito adiante". E o discurso de Sílvio retorna. Aí, vemos o modo como o Estado lida com a memória, fabricada, parcial, incinerando documentos, arquivos, escondendo os corpos, dos quais nos restaram, por azar do regime, e sorte para a cultura brasileira, o filme aqui analisado, guardado nos arquivos do Museu.

Ao som de Señor tiene piedad de nosotros, volta-se a visão caleidoscópica, outra profusão de imagens diversas, do fuzilamento dos jovens, de uma sala de espera pós-tortura, em que uma outra jovem ensaia uma dança, e logo a cena volta para a sala de aula do início do filme. Os estudantes escutam a notícia sobre a repressão. Alda diz: "Canalhas! [...] Mas eles me encontrarão de pé!", e inicia a dança que vimos no início do filme. Manhã cinzenta termina com o assassinato do casal, ao som da canção "Credo", da Misa Criolla, em desejo que a esperança não morra com eles: "Padre todo poderoso creador de Cielo y Tierra / y en Jesucristo creo".

Quanto às questões especificamente técnicas e de linguagem cinematográfica que são marcantes no filme de Olney, está a relação entre música e imagem, que atribui à obra sentidos e sentimentos maiores. As músicas orquestradas eram utilizadas nos filmes ditando seus ritmos, com intuito de aflorar sentimentos e sensações no público, como nas animações de Walt Disney.

No momento da realização de Manhã cinzenta, o uso da música havia alcançado novos patamares. A novidade era a utilização de músicas populares cantadas nos

\footnotetext{
11 Inspirada na Campanha de alfabetização cubana, a campanha brasileira, iniciada em 1963, foi extinta pelo golpe civil-militar, e Paulo Freire foi preso e exilado como subversivo.
} 
filmes, como a canção The sound of silence, de Simon \& Garfunkel, no filme estadunidense The Graduate (1968) de Mike Nichols; ou, as canções do filme Deus e o Diabo na terra do sol (1964), de Glauber Rocha, onde foram empregadas com o mesmo senso não diegético.

No caso do filme de Olney, as músicas exercem, além da função irônica discutida anteriormente, outras funções, a começar por reiterar a mudança de ambiente e situação, como quando os créditos iniciais mostram o ambiente urbano ao som da já referida Gloria, que funciona como elemento extradiegético, ou quando a cena corta para a sala de aula em que Alda está dançando ao som de uma música popular, a qual funciona como um elemento diegético.

Além de marcar a mudança de ambiente e situação, a música em Manhã cinzenta atua como recurso estilístico, no sentido de enfatizar, por exemplo, a relação autoritarismo e liberdade, real e ficcional. Isto se verifica, como vimos, na utilização das marchas de John Philip Sousa por Olney, para criar um jogo de contrários na relação das culturas sonoras com as imagens apresentadas. Outro exemplo concreto é a estilística exercida pela música popular (rock and roll) tocada na sala enquanto Alda dança, cena aparentemente banal, onde a canção e as imagens resultam numa estilística que potencializa as intenções do cineasta em situar o espectador em um período cultural específico e caracterizar os jovens ali apresentados, o que será interessante para o resultado final do filme.

Ainda com relação à técnica, salientamos que, além dos valores estilísticos e temáticos do Cinema Novo, Manhã cinzenta se aproxima das produções italianas neorrealistas. Isto se torna patente na mescla de documentário e ficção, na junção de cenas reais e encenadas, como nos filmes Roma Città Aperta (1945), de Roberto Rossellini, e La Terra Trema (1948), de Luchino Visconti. O primeiro mostra a união da população de Roma (que havia sido declarada "cidade aberta" aos nazistas, a fim de evitar seus bombardeios), para a resistência contra os nazistas após a queda de Mussolini; para a filmagem utilizaram atores profissionais e não atores, em locações reais. Já no segundo, estão presentes questões sociais e políticas, que acompanham personagens de proletários explorados, os quais lutam por condições melhores de vida, mas têm suas tentativas frustradas; os atores não eram profissionais, mas habitantes da região, envolvidos nos problemas reais apresentados pelo filme, cuja utilização do ambiente e do contexto reais, aproxima-o do realismo.

As escolhas visuais de Olney também envolvem as questões estéticas ousadas, revigoradas pelos novos movimentos naquele período em todo o mundo. Mais ainda: ele as utiliza e as combina de forma própria, unindo a elas sua temática político-social e o estilo não linear, de eventos de tortura e repressão, o que chamamos de "estilhaços em sequência". Nas poucas vezes que o diretor opta por manter a câmera fixa, nota-se o desenvolvimento na relação entre os primeiros, segundos e até terceiros planos, como nas cenas que se passam na sala de aula, onde após planos gerais que mostram o ambiente e toda a turma, as imagens cortam para mostrar os alunos, colocando dois ou três personagens, cada um com um foco di- 
ferente captado, criando um deslocamento da profundidade. Nas cenas com a câmera fixa, o cineasta utiliza em alguns momentos formas geométricas, como nos que mostram o protagonista masculino em primeiro plano, e outros dois alunos em segundo plano, cada qual em uma extremidade do quadro, criando formas triangulares que atribuem à imagem harmonia e plasticidade visual (técnica no cinema que advém das pinturas).

Destacamos, nas cenas internas, o bom aproveitamento que o cineasta faz do "ponto ideal" para se filmar, muitas vezes situando o espectador no ambiente (não apenas em planos abertos, mas também com planos mais fechados e até mesmo com alguns inserts) onde estão os personagens, ou onde eles se deslocam, mas sempre tendo em vista a posição relativa destes. Em relação ao uso da iluminação (a despeito do mau estado da cópia existente), é curioso notar o cuidado do cineasta em definir seus personagens e ambientes em um traçado singular por conta da iluminação, ficando evidente tal apuro em planos mais fechados.

Um exemplo de técnica cinematográfica própria de Olney é a movimentação da câmera, em um travelling lateral, realizado no início do filme, em que a câmera caminha da vista da cidade até focalizar Alda, que se posiciona em frente à janela. Nesse momento, o enquadramento e a posição da câmera proporcionam um contraluz, destacando a silhueta da moça (algo bem usado nos Westerns de Ford, que eram uma referência para ele). Como dissera o próprio cineasta: "o cinema foi um vento norte jogado em minhas veias primeiro pela força criadora de John Ford" (CALBO, 2002, p. 3). A diferença fica por conta da iluminação que se altera, "revelando" novamente o rosto e corpo da personagem, o que causa um efeito estilístico elaborado e particular. O uso do desenquadramento também reforça estas pulsões visuais que o diretor utiliza, além dos planos médios e primeiros planos, que criam variações dinâmicas nos quadros.

O domínio na fotografia do filme fica por conta da "câmera na mão", artifício que ficou popular com o Cinema Novo. Olney acrescenta suas próprias escolhas estéticas a esse estilo de filmagem com os já citados enquadramentos, e também com suas movimentações de câmera, com força para travellings laterais, para frente e para trás, sempre tendo em vista acompanhar os personagens se deslocando. Todas as técnicas e escolhas estéticas do diretor se juntam e despertam um interesse ainda maior em relação à história narrada. Quanto à edição, esta (re)apresenta a trama de maneira não linear, forçando o próprio espectador a ligar os acontecimentos, fazendo ele mesmo as ligações lineares das cenas. ${ }^{12}$ Em um momento de entusiasmo no cinema mundial, de opressão política e censura no Brasil, Olney, um cineasta autodidata, faz, por meio de suas ideias e seu amor ao cinema, uma narrativa aguerrida e comovente de sua visão política dos regimes ditatoriais.

\footnotetext{
12 Isso pode ser relacionado às montagens russas em filmes como A greve (1925), de Serguei Eisenstein.
} 


\section{Montagem dos estilhaços}

A narrativa de Manhã cinzenta é composta pela edição de estilhaços - como caleidoscópio de cenas colocadas em sequência, a fim de torná-las legíveis - que alegoriza os rompimentos que aconteceram com o golpe: as excepcionalidades que passaram a ser regra, a suspensão dos direitos fundamentais, o despedaçamento das instituições democráticas, da liberdade de expressão e, por extensão, o estilhaçamento dos corpos. E do "Brasil, país do futuro", bordão criado a partir do livro de Stefan Zweig, na promessa de civilização da ditadura Vargas, que chegaria ao futuro, pelas mãos dos militares, em 1964, arremessado violentamente como um "presente" dilacerado. Sua temática - a repressão e a tortura - corroboram o adjetivo "bárbaro", empregado por Glauber, enquanto seu apuro técnico/estético, sublinham sua sofisticação, tal como adjetivado pelo mesmo cineasta.

Ao dialogar com o contexto em que foi realizado, o filme pode ser percebido como um "agente da História", no sentido proposto por Ferro (1992). Seu agenciamento histórico, assinale-se, se faz de modo diferenciado, pois, ao incorporar imagens reais do que ocorria nas ruas do Rio de Janeiro em 1968, o filme se torna um registro da história no momento mesmo de seu acontecimento. Ainda na perspectiva de Ferro, a completa compreensão de um filme como documento histórico pode ser alcançada quando o observamos no contexto da realidade representada. Ocorre-nos, entretanto, que o filme analisado ultrapassa seu próprio contexto, não apenas ao tomar o nazismo como referencial dos regimes totalitários, conforme já citado, e a ditadura brasileira, em curso naquele momento, mas ao indiciá-los não como momentos de exceção na história dos povos e sim como regra, uma presença latente nas sociedades, tal como o bacilo da peste que fica adormecido por dezenas de anos, mas que a qualquer momento pode ser acordado. A menção ao trecho do livro A peste, de Albert Camus, aproxima o filme não apenas ao Existencialismo, como também ao pensamento de Walter Benjamin, quando ensina que, ao compreendermos a opressão como regra e não como exceção, construímos um novo conceito de história, não mais sob a ótica do opressor, mas calcado na tradição dos oprimidos, evitando, inclusive, que a violência e o aniquilamento dos indivíduos perpetrados por tais regimes não se extingam da memória dos povos (BENJAMIn, 1985). Manhã cinzenta escreveu em imagens, ora metafóricas, ora reais, um capítulo da história brasileira contemporânea, tornando-se, ele próprio, um objeto histórico, um fragmento/estilhaço dessa mesma história.

\section{Referências}

Aragão, Hudson Oliveira Fontes. Ironia e literatura: interseções. Anais do SILEL, Uberlândia, v. 3, n. 1, p. 1-14, 2013. Disponível em: <www.ileel.ufu.br/anaisdosilel/wpcontent/uploads/2014/o4/silel2013_1467.pdf >. Acesso em: 22 ago. 2017. 
Benjamin, Walter. Sobre o conceito de história. In: Benjamin, Walter. Obras escolhidas I: magia e técnica, arte e política. Tradução de Sergio Paulo Rouanet. São Paulo: Brasiliense, 1985. p. 222-232.

Bierley, Paul E. Fohn Philip Sousa: American phenomenon. Miami: Warner Bros Publications, 1973.

Calbo, Iza. A morte e a morte de Olney São Paulo. Neon, Salvador, ano $4, \mathrm{n}$. 34, 2002. Disponível em: <http://www.recantodasletras.com.br/artigos/1072386>. Acesso em: 26 jul. 2017.

Dantas, Henrique. Ser tão cinzento. Brasil: Hamaca Filmes, 2011. Documento digital, Documentário, 25 min., P\&B. Trilha original de Ilya São Paulo.

Dantas, Henrique. Sinais de cinza: a peleja de Olney contra o dragão da maldade. Produção de Hamaca Produções. Brasil: Distribuição Livres Filmes, 2017. Documentário, 88 min., col. Trilha de Ilya São Paulo.

Derrida, Jacques. Escritura e diferença. 2. ed. Tradução de Maria Beatriz da Silva. São Paulo: Perspectiva, 1995.

DíAz, Claudio F. Una vanguardia en el folklore argentino: canciones populares, intelectuales y política en la emergencia del "Nuevo Cancionero". In: CoNgreso Nacional Celehis de Literatura, 2., 25 a 27 nov. 2004, Mar del Plata. Anais... Buenos Aires: Universidad Nacional de Mar del Plata, 2004. Disponível em: <http://www.mdp.edu.ar/humanidades/letras/celehis/congreso/2004/actas/ ponencias/9/2_Diaz.doc $>$. Acesso em: 13 set. 2017.

Ferro, Marc. Cinema e história. Tradução de Flávia Nascimento. Rio de Janeiro: Paz e Terra, 1992.

Hutcheon, Linda. Teoria e política de ironia. Tradução de Julio Jeha. Belo Horizonte: Editora da UFMG, 2000 .

José, Angela. Olney São Paulo e a peleja do cinema sertanejo. Rio de Janeiro: Quartet, 1999.

MACHADO, Irene. Memória da cultura em espaços de relações dialógicas: o caso do cinema político. In: EnConTro AnUAL DA Compós, 25., 7 a 10 jun. 2016, Universidade Federal de Goiás. Anais... Goiânia: Compós, 2016. p. 1-26. Disponível em: $<$ http://www.compos.org.br/biblioteca/compos-2016_3416.pdf>. Acesso em: 13 set. 2017.

Nicolazzi, Fernando. Algumas reflexões sobre história e cinema. História da historiografia, Ouro Preto, n. 6, p. 190-198, mar. 2011.

Pinto, Leonor E. Souza. (Des)caminhos da censura no cinema brasileiro: os anos de ditadura. Memória da Censura no Cinema Brasileiro - 1964-1988. On-line. Disponível em: <http://www.memoriacinebr.com.br>. Acesso em: 14 jun. 2017. 
Ramírez, Ariel. Gloria (Carnavalito-Yaraví). In: Ramírez, Ariel. Misa Criolla / Navidad Nuestra. Charango: Jaime Torres. Argentina: Philips, 1964.

Rıos, Dinameire Oliveira Carneiro. O cinema de Olney São Paulo: Grito da terra e o cinema nacional. Dissertação (Mestrado em Literatura e Diversidade Cultural) - Universidade Estadual de Feira de Santana, Feira de Santana, 2013.

Rocha, Glauber. Revolução do Cinema Novo. Rio de Janeiro: Alhambra; Embrafilme, 1981.

Rosenstone, Robert A. História nos filmes, os filmes na história. São Paulo: Paz e Terra, 2010.

SAntos, Maria David. Olney São Paulo: maldição e esplendor em Manhã cinzenta. Dissertação (Mestrado em Literatura e Diversidade) - Universidade Estadual de Feira de Santana, Feira de Santana, 2013.

São Paulo, Olney Alberto. Manhã cinzenta. In: SÃo Paulo, Olney Alberto. A antevéspera e o canto do sol: contos e novelas. Rio de Janeiro: José Álvaro, 1969. p. 15-21.

São Paulo, Olney Alberto. Manhã Cinzenta. Produção: Olney Alberto São Paulo e Ciro de Carvalho Leite. Fotografia: José Carlos Avelar. Brasil, 1969. 22min, P\&B, $35 \mathrm{~mm}$.

Senna, Orlando. Humanismo e poesia. In: Associação Brasileira de Documentaristas e Curta-Metragistas. Dia do documentário. [S.l.]: ABD, 2011. Disponível em: <http://lproweb.procempa.com.br/pmpa/prefpoa/smc/usu_doc/manha_ cinzenta.pdf $>$. Acesso em: 14 jun. 2017.

Veloso, Caetano. É proibido proibir. Álbum É Proibido Proibir / Ambiente de Festival. São Paulo: Philips, 1968. Disco: 7", 33 1/3 RPM, mono. 365.257-A.

Recebido em 27 de setembro de 2017.

Aprovado em 7 de março de 2018.

\section{Resumo/Abstract/Resumen}

Por dentro do caleidoscópio: história e memória político-cultural em $\mathrm{Ma}$ nhã cinzenta, de Olney São Paulo

\section{Antonia Cristina de Alencar Pires \\ Gustavo Cesário de Souza Tanus \\ Filipe Schettini}

Neste tempo presente, não há como dissociar arte e política, que se realizam nos mesmos pontos dos textos: na forma ou no conteúdo, ou em ambos. Manhã cinzenta (1969), média-metragem do cineasta baiano Olney São Paulo, é significativo 
em relação aos engajamentos artísticos e políticos, sendo um dos mais importantes filmes da resistência contra a ditadura civil-militar de 1964, por realizar uma leitura e interpretação do contexto histórico no momento de seu acontecimento, sendo também uma espécie de metáfora da vida do próprio cineasta, afigurandose como uma ferida em seu corpo estilhaçado pela tortura. Embasamos nossa leitura e análise nos pressupostos teóricos de Marc Ferro (1971; 1992) e de Robert Rosenstone (2010) de que os filmes e os arquivos fílmicos podem suprir a ausência dos documentos oficiais tradicionais, dos quais a história lança mão para construir seu discurso, sendo, portanto, em sentido derridiano, suplementares para a construção historiográfica, podendo ser fontes para a compreensão de contextos e de acontecimentos históricos.

Palavras-chave: cinema, história, memória cultural, Manhã cinzenta, Olney São Paulo.

Look inside the kaleidoscope: history and political-cultural Memory in Manhã Cinzenta, by Olney São Paulo

\section{Antonia Cristina de Alencar Pires Gustavo Cesário de Souza Tanus Filipe Schettini}

In this present time, there is no way to dissociate art and politics, which take place at the same points in the texts: in form and / or content, or both. Manhã Cinzenta (1969), medium-length film by the filmmaker Olney São Paulo, is significant in relation to artistic and political engagements, being one of the most important films of the resistance against the civil-military dictatorship of 1964 , for performing a reading and interpretation of the historical context at the time of its happening, being also a kind of metaphor of the life of the own filmmaker, appearing like a wound in its body shattered by the torture. We base our reading and analysis on the theoretical assumptions of Marc Ferro $(1971,1992)$ and Robert Rosenstone (2010) that films and film archives can make up for the absence of traditional official documents, discourse, being, therefore, in Derridian sense, supplementary for the historiographical construction, being able to be sources for the understanding of historical contexts and events.

Keywords: cinema, history, cultural memory, Manhã cinzenta, Olney São Paulo.

\section{Por dentro del caleidoscopio: historia y memoria político-cultural en $\mathrm{Ma}$ -} nhã cinzenta, de Olney São Paulo

\section{Antonia Cristina de Alencar Pires Gustavo Cesário de Souza Tanus Filipe Schettini}


En este tiempo presente, no es posible disociar arte y política, que se realizan en los mismos puntos de los textos: en la forma o en el contenido, o en ambos. Manhã cinzenta (1969), el metraje del cineasta bahiano Olney São Paulo, es significativo en relación a los compromisos artísticos y políticos, siendo una de las más importantes películas de la resistencia contra la dictadura civil-militar de 1964, por realizar una lectura e interpretación del cine el contexto histórico en el momento de su acontecimiento; siendo también una especie de metáfora de la vida del propio cineasta, como una herida en su cuerpo destrozado por la tortura. Basamos nuestro análisis en los presupuestos teóricos de Marc Ferro (1971; 1992) y de Robert Rosenstone (2010), de que las películas y los archivos fílmicos pueden suplir la ausencia de los documentos oficiales tradicionales, a partir de los cuales la historia se lanza a construir su propio discurso, y, por lo tanto, en sentido derridiano, resultan suplementarios para la construcción historiográfica, pudiendo ser fuentes para la comprensión de contextos y de acontecimientos históricos.

Palabras clave: cine, historia, memoria cultural, Manhã cinzenta, Olney São Paulo. 